Article

\title{
Dual-Temperature Evaluation of a High-Temperature Insulation System for Liquid-Immersed Transformer
}

\author{
Xiaojing Zhang ${ }^{1}$, Lu Ren ${ }^{1}$, Haichuan $\mathrm{Yu}^{1}$, Yang Xu ${ }^{1, *}$, Qingquan Lei ${ }^{1}$, Xin $\mathrm{Li}^{2}$ and Baojia Han ${ }^{3}$ \\ 1 State Key Laboratory of Electrical Insulation and Power Equipment, Xi'an Jiaotong University, No. 28 \\ Xianning West Road, Xi'an 710049, China; Emma.Zhang@dupont.com (X.Z.); renluxjtu@163.com (L.R.); \\ hnbcyhc@stu.xjtu.edu.cn (H.Y.); lei_qingquan@sina.com (Q.L.) \\ 2 Electric Power Research Institute of Guangdong Power Grid Corporation, No.6-8 Dongfeng East Road, \\ Guangzhou 510062, China; lihongxin0303@163.com \\ 3 Guangdong Zhongpeng Electricity Co., Ltd., No.19 Qianjin Road, Foshan 528000, China; \\ hanbaojia@hotmail.com \\ * Correspondence: xuyang@xjtu.edu.cn; Tel.: +86-029-82665415
}

Received: 5 July 2018; Accepted: 24 July 2018; Published: 27 July 2018

\begin{abstract}
A high-temperature oil-paper insulation system offers an opportunity to improve the overloading capability of distribution transformers facing seasonal load variation. A high-temperature electrical insulation system (EIS) was chosen due to thermal calculation based on a typical loading curve on the China Southern Power Grid. In order to evaluate candidate high-temperature insulation systems, Nomex ${ }^{\circledR}$ T910 (aramid-enhanced cellulose) immersed in FR3 (natural ester) was investigated by a dual-temperature thermal aging test compared with a conventional insulation system, Kraft paper impregnated with mineral oil. Throughout the thermal aging test, mechanical, chemical, and dielectric parameters of both paper and insulating oil were investigated in each aging cycle. The thermal aging results determined that the thermal class of the FR3-T910 insulation system meets the request of overloading transformer needs.
\end{abstract}

Keywords: liquid-immersed transformer; thermal aging; Nomex T910; natural ester; dual-temperature

\section{Introduction}

Urbanization in China has led to the population moving between urban and rural areas, which results in seasonally fluctuating electrical power demand, particularly overloading rural transformers during the Chinese spring festival and plowing seasons. Traditionally, the adoption of higher-capacity transformers was considered by utilities to handle overloading. However, this decreases the normal loading rate and yields a lower efficiency.

The State Grid Corporation of China published technical guidance for overloading rural transformers in 2014 [1], and identified the typical loading curve. China Southern Power Grid released a similar typical loading curve, shown in Figure 1 [2]. On the basis of the normal temperature-rise test requirements, the transformer should meet the requirement for continuous operation of $6 \mathrm{~h}$ at 1.5 times rated power, $3 \mathrm{~h}$ at 1.75 times rated power, and $1 \mathrm{~h}$ at 2 times rated power. A conventional insulation system, Kraft paper and mineral oil, has been utilized as a principal insulation system in liquid-immersed transformers. A typical thermal class of Kraft paper is $105^{\circ} \mathrm{C}$, which allows an average winding temperature rise of $55 \mathrm{~K}$ [3]. Meanwhile, the flash point of mineral oil is about $140{ }^{\circ} \mathrm{C}$, which raises fire safety concerns for the industry. 


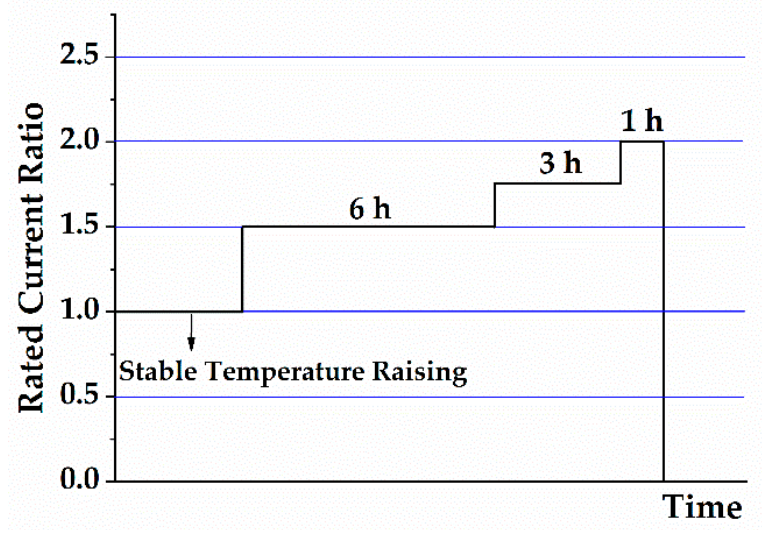

Figure 1. Loading curve for overloading distribution transformers required by Southern Grid [2].

The sustainable solution is to improve the overloading capacity of distribution transformers by adopting a thermally upgraded insulation system. Natural and synthesized esters have been developed in the past, focusing on fire safety and environmental footprint. Several researchers [4-6] have reported that natural ester is beneficial in alleviating the deterioration of paper and prolonging its life, due to the high hydrophilicity and the transesterification effect on cellulose of natural ester. Based on the thermal calculation referring to a typical loading curve, the maximum hot spot temperature is $117.9^{\circ} \mathrm{C}$ for the distribution transformer (S13-m(b)-400/10). In order to meet the high-temperature needs of insulation paper, Nomex ${ }^{\circledR}$ T910 was introduced globally in 2014 as an alternative insulating paper for liquid-immersed transformers.

As shown in Figure 2, Nomex ${ }^{\circledR}$ T910 is a type of aramid-enhanced cellulose paper with a three-layer sandwich structure. The center ply is made of $100 \%$ cellulose, like normal Kraft paper, but the outer two plies are made of $50-70 \%$ cellulose blended with $30-50 \%$ aramid materials. Three plies are consolidated into a single sheet by a paper manufacturing processes such as wet forming, drying, and densification. The reason why T910 has higher thermal performance than cellulose paper is that the aramid fiber can enhance the thermal stability of the cellulose paper, and the fiber ratio between aramid fiber and cellulose fiber will determine its performance. The dispersal states will be different when the ratios of aramid fiber and cellulose fiber are different, as shown in Figure 2.

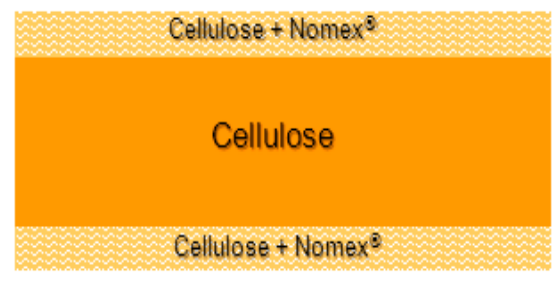

(a)

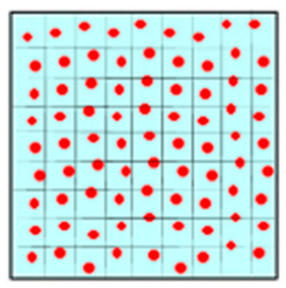

(b)

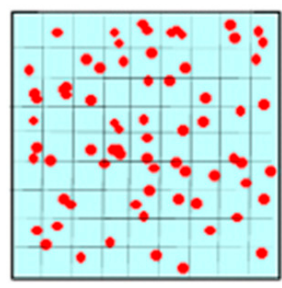

(c)

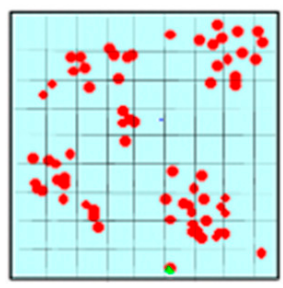

(d)

Figure 2. The structure of T910 [7] and different dispersal states of aramid fiber in cellulose fiber under different ratios: (a) structure of T910; (b) regular, with ratio less than 5\%; (c) random, with ratio between $10 \%$ and $25 \%$; (d) clumped, with ratio higher than $30 \%$.

Once the ratio of aramid fiber is lower than $5 \%$, the thermal or electrical chambers between modules are similar to those of cellulose paper. If the aramid fiber ratio is increased to $10-25 \%$, cellulose fiber will distribute randomly in the paper, which improves the paper's performance. Furthermore, when the aramid fiber ratio is increased to $30 \%$, cellulose fibers will be surrounded by aramid fiber. The traditional thermal chambers between cellulose fibers have been blocked to improve the thermal performance of paper significantly, and the final content of aramid fiber in the center ply is about 
30-50\%. As shown in Figure 3, the Thermal Gravimetric Analyzer (TGA) results of both Kraft and T910 have been analyzed. Although the initial decomposition temperature of T910 is $310.87{ }^{\circ} \mathrm{C}$, the secondary decomposition of T910 has been improved to $529.32{ }^{\circ} \mathrm{C}$, compared with Kraft by aramid fibers, which potentially bring the benefit of high temperature thermal stability.

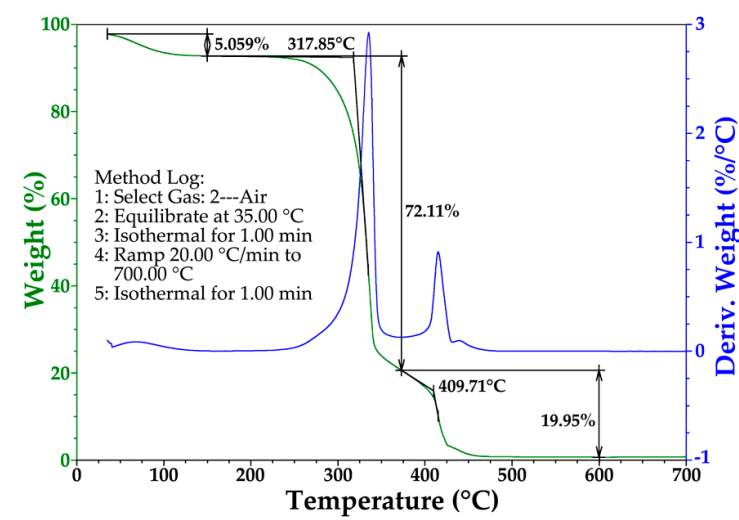

(a)

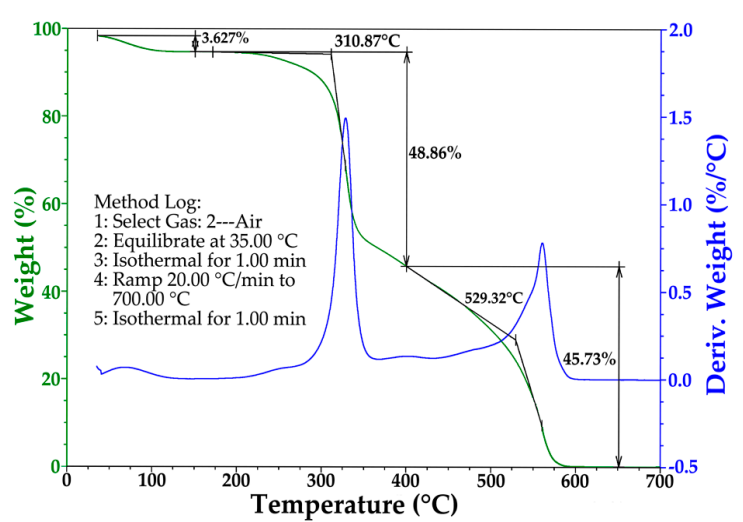

(b)

Figure 3. TGA results of insulating papers: (a) cellulose paper; (b) T910.

Before applying a new insulation system to the transformer, a thermal aging test should be done to test its thermal class or thermal index. According to [7], the thermal class of mineral oil-impregnated $\mathrm{T} 910$ is considered to be $130^{\circ} \mathrm{C}$. The tensile strength of mineral oil decreases slightly after $250 \mathrm{~h}$ thermal aging under $150{ }^{\circ} \mathrm{C}$, or $500 \mathrm{~h}$ thermal aging under $130{ }^{\circ} \mathrm{C}$ [8]. However, there are no details or results on the thermal aging of natural ester impregnated T910.

Three accelerated thermal aging methodologies can be adopted to evaluate the thermal aging performance of a new insulation system, as follows. IEEE Std. C57.100 ${ }^{\mathrm{TM}}$ [9] gives a description of functional life aging, called the Lockie method, which is closer to the real operation by introducing a distribution or power transformer model with high cost. Another approach, the sealed tube method, is commonly adopted due to its convenience; this method has been described in IEC 62332-2 [10]. The latest aging method, the dual-temperature test, was introduced in IEC 62332-1 [11], and simulates operational status, including the different temperatures between insulating paper and oil as well as oil flow, which are the limitations of seal tube tests. According to research by Wicks [12], the two evaluations, the dual-temperature aging method and the Lockie method, are similar for the same insulation system.

In this paper, in order to evaluate the thermal aging performance of T910-FR3 and Kraft paper-mineral oil, thermal aging tests were conducted by using the dual-temperature platform, which was adjusted to simulate real transformer winding compared to the structure of IEC 62332-1.

\section{Experimental Methods}

\subsection{Materials}

The insulating paper tested for this study included Nomex ${ }^{\circledR}$ T910 paper $(0.08 \mathrm{~mm})$ manufactured by DuPont and Kraft paper $(0.08 \mathrm{~mm})$ by Nine Dragons Paper, as well as high-density pressboard $\left(1.17 \mathrm{~g} / \mathrm{cm}^{3}\right)$. Insulating oil included FR3 from Cargill and No. 25 mineral oil (MO) from Nan You Petrochemical. The basic properties of the different oils and papers are shown in Table 1. 
Table 1. Basic properties of insulating oils and insulating papers.

\begin{tabular}{|c|c|c|c|c|c|}
\hline Properties & \multicolumn{2}{|c|}{ Insulating Oil } & Properties & \multicolumn{2}{|c|}{ Insulating Paper } \\
\hline Appearance & Clear & Light Green & Thickness (mm) & 0.08 & 0.08 \\
\hline Viscosity, $40^{\circ} \mathrm{C},\left(\mathrm{mm}^{-2} \cdot \mathrm{s}^{-1}\right)$ & 8.01 & $32-34$ & Tensile Strength, MD $\left(\mathrm{N} \cdot \mathrm{cm}^{-1}\right)$ & 64.7 & 70 \\
\hline Flash Point, $\operatorname{PMCC}\left({ }^{\circ} \mathrm{C}\right)$ & 155 & 255 & Tensile Strength, $\mathrm{XD}\left(\mathrm{N} \cdot \mathrm{cm}^{-1}\right)$ & 38.6 & 17 \\
\hline Acid Value $\left(\mathrm{mg} \mathrm{KOH} \cdot \mathrm{g}^{-1}\right)$ & 0.0011 & $0.013-0.042$ & AC Breakdown Voltage, Air $\left(\mathrm{kV} \cdot \mathrm{mm}^{-1}\right)$ & 10.4 & 20 \\
\hline
\end{tabular}

\subsection{Dual-Temperature Thermal Aging Platform}

As shown in Figure 4, the dual-temperature test platform includes an aging cell, power supply system, heating elements, control system, safety protector, and sampling unit. The aging cells in the tests were modified based on IEC 62332-1 [11], as labeled in Figure 5. The outer diameter of the cell is $220 \mathrm{~mm}$ and the length is $420 \mathrm{~mm}$. The aging cell consists of both an insulating oil-paper test object sample and corresponding heaters and sensors, in which temperature monitoring of solid and liquid materials is separately realized by the copper conductor and immersion heaters coordinating with their individual thermal sensors. The insulating oil circulates in the aging cell due to the temperature difference to simulate the oil flow in transformers.

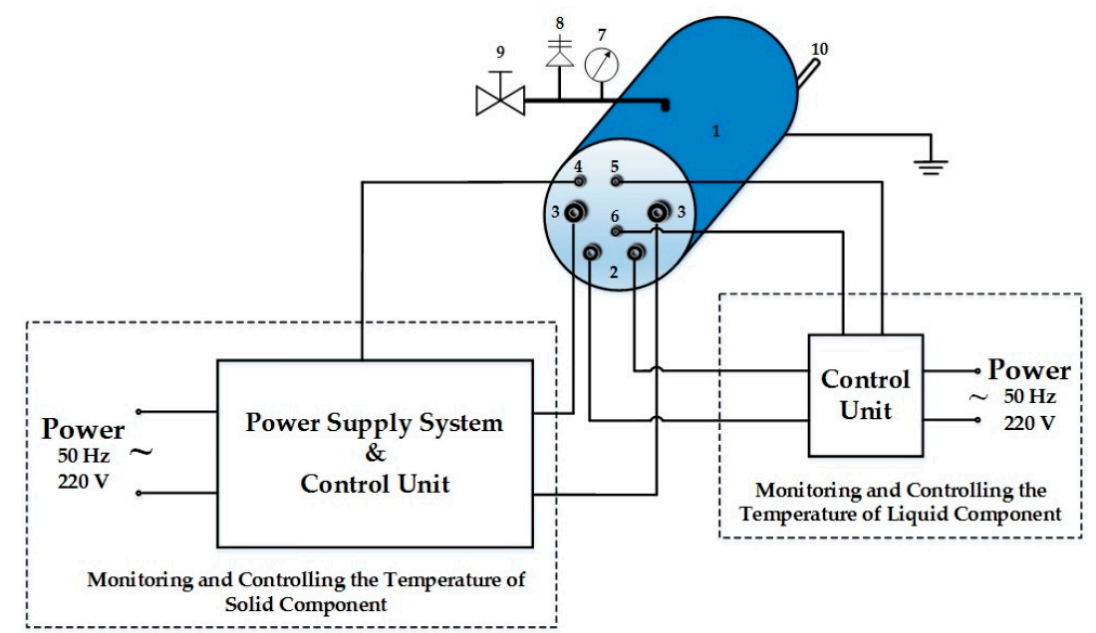

(a)

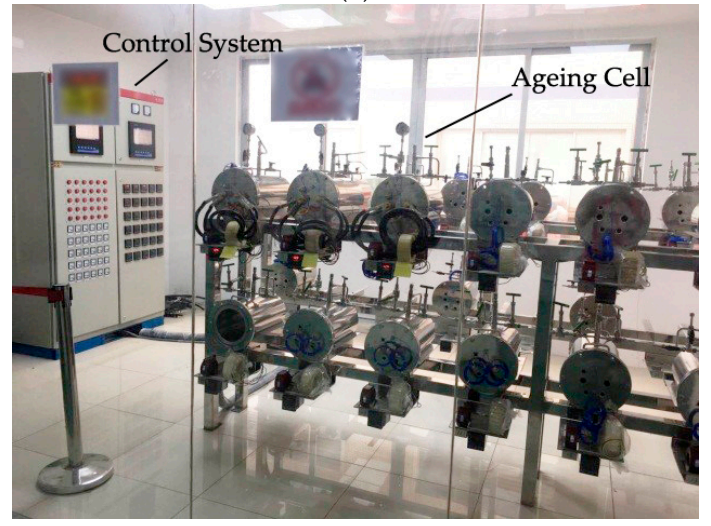

(b)

Figure 4. Dual-temperature thermal aging platform: (a) schematic diagram (1, aging cell; 2, immersion heaters for liquid; 3 , copper conductor; 4 , temperature sensor for solid component; 5 , temperature sensor located at liquid surface; 6 , temperature sensor located at liquid center; 7 , barometer; 8 , relief valve; 9, gas valve; 10, liquid pipeline); (b) photo. 


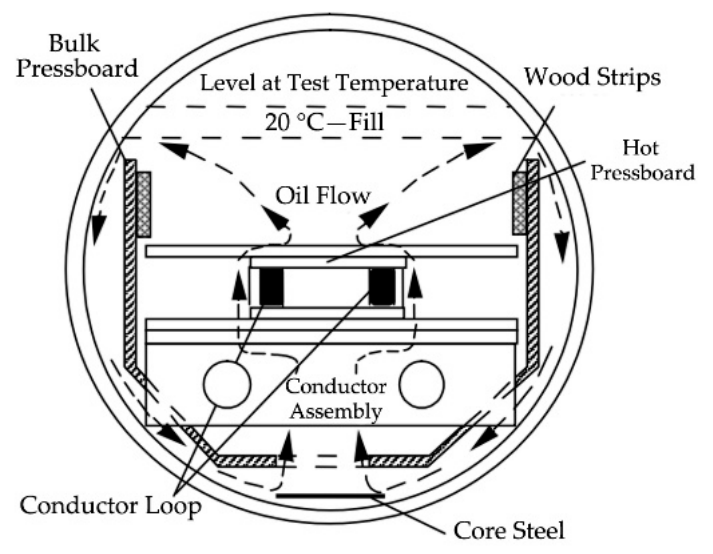

Figure 5. Sectional view of aging cell [11].

The solid samples are mainly composed of a copper conductor, the insulating papers to be evaluated, and a pressboard. The copper conductor, made into an $\mathrm{M}$ type, is used to simulate the winding of the transformer, which is first wrapped with paper tape in a half-lapping way to prevent contamination of test samples, then by tensile and breakdown samples in sequence, and finally, by paper tape, as in the first step for fixing. The $\mathrm{M}$ type copper conductor wrapped with paper is tightly bound with copper wires and high-density pressboard, in order to simulate transformer winding conditions. Considering the temperature differences among the 4 parts of the conductor, test samples are classified into outer layer samples and inner layer samples. There are 7 layers for both inner layer and outer layer: 1 layer for foundation, 5 layers for tensile strength, breakdown voltage, and initial tear strength test, and 1 layer for protection. The difference between them is the temperature difference based on thermal radiation. Thermal sensors are located between the first layer and tensile samples, in order to reflect the temperature of the tensile samples. As shown in the internal view of an aging cell in Figure 6, the copper conductor is fixed to the lid of the aging cell, and connected to the power system using fluororubber for sealing and insulation.

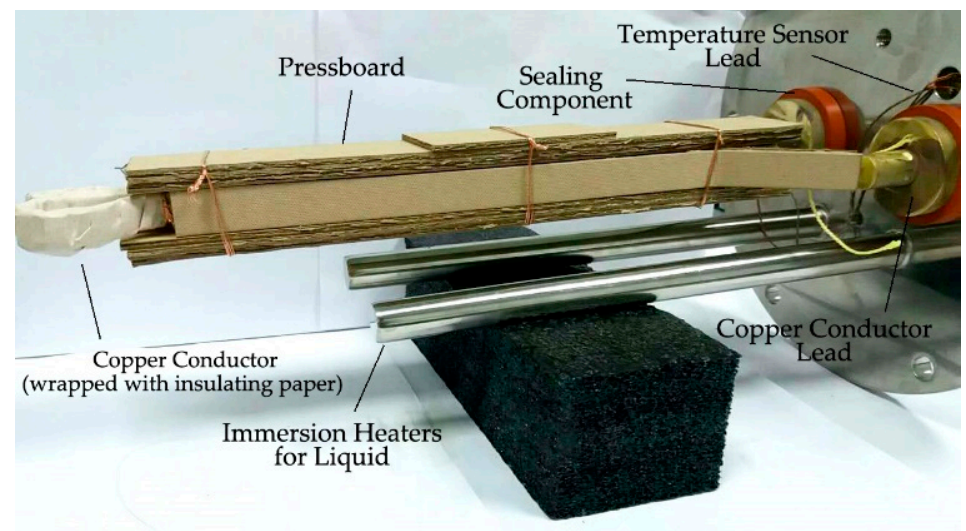

Figure 6. Sample of internal view of aging cell.

To make the test cell reasonable, the volume ratios of materials are selected according to the recommendations of IEC 62332-1 [11]. In this test, the oil sample consumption is about $10.3 \mathrm{~L}$. The calculation allowed the determination of material volume ratios as follows: $474 \mathrm{~cm}^{3}$ of high-temperature insulation (which includes the insulation and the pressboard in high-temperature areas), $1140 \mathrm{~cm}^{3}$ of low-temperature insulation (which includes low-temperature pressboard and additional samples for material balance), and $214 \mathrm{~cm}^{2}$ of silicon steel. Specifically, $474 \mathrm{~cm}^{3}$ high-temperature insulation includes $18 \mathrm{~cm}^{3}$ candidate insulating paper sample, $115 \mathrm{~cm}^{3}$ of paper 
for the wrapped conductor, and $341 \mathrm{~cm}^{3}$ of high-density pressboard. The thickness of all paper for wrapped conductors is $0.08 \mathrm{~mm}$. In this paper, 2 insulation systems were tested: Kraft paper-mineral oil as the benchmark system, and T910-FR3 ester as the candidate system. Both of them had the same volume ratio of insulating paper and oil, but different mass ratio based on different densities. Each aging cell includes $118 \mathrm{~g}$ of Kraft or $133 \mathrm{~g}$ of T910, $399 \mathrm{~g}$ of high-density pressboard for high temperature insulation, and $510 \mathrm{~g}$ of high-density pressboard for the low temperature pressboard. For insulating oil, mineral oil was $8.73 \mathrm{~kg}$ in the conventional insulation system, and FR3 was $9.48 \mathrm{~kg}$ in the high-temperature insulation system.

\subsection{Sample Pretreatment}

All the insulating oil and papers should be preconditioned before the test. The insulating oil should be dehydrated and degassed under vacuum conditions by using the apparatus shown in [13]. At the same time, the insulating paper should be dehydrated under high temperature. Figure 6 shows the assembly of the insulation paper, high-density pressboard, and other accessories. As the last step in the dehydration process, the aging cell was put into the oven with open valves after sealing. As the preconditioning result, water contents of the materials are listed in Table 2.

Table 2. Water contents of insulating oil and paper after preconditioning.

\begin{tabular}{ccccc}
\hline \multirow{2}{*}{ Property } & \multicolumn{2}{c}{ Insulating Oil } & \multicolumn{2}{c}{ Insulating Paper } \\
\cline { 2 - 5 } & MO & FR3 & Kraft & T910 \\
\hline Water Content & $17.1 \mathrm{ppm}$ & $147.4 \mathrm{ppm}$ & $0.503 \%$ & $0.426 \%$ \\
\hline
\end{tabular}

Furthermore, the pipeline of the aging cell was connected to the processed oil, and the gas valve was connected to the vacuum pump to keep the low pressure of the aging cell. Insulating oil in the amount of $10.3 \mathrm{~L}$ was injected into the aging cell. After the oil injection and vacuum process, the valves were closed and the aging cell was put into the oven. The solid samples were impregnated with corresponding insulating oil at $90^{\circ} \mathrm{C}$ for $12 \mathrm{~h}$ under vacuum conditions to soak in fully. After the impregnation process, the absorption of T910 with FR3 was 42.1\%, and that of Kraft paper with mineral oil was $37.5 \%$, based on the density difference and fiber polarity variance of the insulating paper.

\subsection{Thermal Aging Test Conditions: Temperature and Aging Period}

To confirm the thermal performance of the candidate system, life assessments of both the candidate and referenced systems at 3 temperatures are necessary, according to the Arrhenius equation. In this paper, the aging temperatures of the copper conductor and insulating oil were separately controlled to simulate hot spot temperature and top oil temperature differences. Details about the aging temperatures and periods of the candidate system and referenced system refer to IEC 62332-1 [11] and are listed in Table 3. After each aging period, the tensile strength and breakdown voltage of insulating paper are measured, as well as water content, acid number, viscosity, and breakdown voltage of insulating oil.

Table 3. Insulation system thermal aging conditions.

\begin{tabular}{|c|c|c|c|c|c|c|c|}
\hline \multicolumn{4}{|c|}{ Reference EIS (MO and Kraft) } & \multicolumn{4}{|c|}{ Candidate EIS (FR3 and T910) } \\
\hline \multirow{2}{*}{$\begin{array}{l}\text { Temp. of } \\
\text { Kraft }\left({ }^{\circ} \mathrm{C}\right)\end{array}$} & \multicolumn{2}{|c|}{ Temp. of Mineral Oil $\left({ }^{\circ} \mathrm{C}\right)$} & \multirow{2}{*}{ Aging Cycle (h) } & \multirow{2}{*}{$\begin{array}{l}\text { Temp. of } \\
\left.\text { T910 ( }{ }^{\circ} \mathrm{C}\right)\end{array}$} & \multicolumn{2}{|c|}{ Temp. of Natural Ester $\left({ }^{\circ} \mathrm{C}\right)$} & \multirow{2}{*}{ Aging Cycle (h) } \\
\hline & Surface & Center & & & Surface & Center & \\
\hline 160 & 124 & 115 & $25 / 50 / 100 / 250$ & 180 & 130 & 115 & $100 / 250 / 500 / 1000$ \\
\hline 140 & 122 & 115 & $250 / 500 / 2000 / 4000 / 5000$ & 165 & 127 & 115 & $500 / 2000 / 4000 / 5000$ \\
\hline 125 & 121 & 115 & $3000 / 4500 / 5000$ & 150 & 125 & 115 & $3000 / 4500 / 5000$ \\
\hline
\end{tabular}




\section{Aging Test Results of Insulating Papers}

\subsection{Tensile Strength of Insulating Papers}

Cellulose is a kind of linear condensation polymer consisting of anhydroglucose; the degree of polymerization (DP) is the average number of glycosidic rings in a cellulose macromolecule [3]. The tensile strength of insulating paper has a direct correlation with DP. When the DP of cellulose paper decreases, the tensile strength will also decrease [14]. In addition, the insulating paper has to endure a certain degree of mechanical stress during the operation of the transformer. Once mechanical fractures appear in the insulating paper, the winding will be directly exposed to the insulating oil, and electrical faults are more likely to occur. Moreover, the locations of fractures can also cause partial discharge as insulating defects. So, the tensile strength of insulating paper is commonly used as an index to evaluate the aging status of the paper [15]. In this study, the tensile strength of insulating paper with different aging statuses was measured according to ASTM D828 [16].

After preconditioning, the initial tensile strength of Kraft paper impregnated with mineral oil was $79.0 \mathrm{~N} / \mathrm{cm}$, and of T910 impregnated with FR3 ester was $84.7 \mathrm{~N} / \mathrm{cm}$. Residual tensile strength was selected to characterize aging status in insulating paper; the calculating method is shown as Equation (1):

$$
R T S=\frac{T S}{I T S} \times 100 \%
$$

where RTS is residual tensile strength, TS is tensile strength after different aging periods, and ITS is the initial tensile strength of the corresponding paper. The results reflect the trend of RTS with aging time, according to IEC 60216-3 [17]. Fifty percent of ITS mentioned in IEC 60216-2 [18] is benchmarked as the lifetime guideline of insulating papers. Figure 7 shows the results of RTS of Kraft and T910 paper at different aging temperatures for the inner and outer layers.

The initial tensile strength of each sample has been treated as $100 \%$ as the initial point before thermal aging process. During the first stage of each aging test, the RTS between the initial point and the first measured point dropped apparently, even more with an increase in temperature. For the comparison between the two layers, the RTS of the inner layer dropped more than that of the outer layer. Furthermore, the scatter points without the initial one are fitted linearly by the method of least squares to determine the lifetime of each insulation system under different aging conditions. As normal practice, the lifetime will be considered as the ageing time when the tensile strength dropped to $50 \%$ of the initial tensile strength. The results of lifetime under each aging temperature are listed in Table 4. The lifetime of the outer insulating paper is higher than that of the inner layer under the same aging temperature due to the difference of heat dissipation situation. The outer layer contacted with insulating oil directly, which leads to a better heat dissipation situation. As expected, the lifetime decreases with the increase of the aging temperature for both insulation systems. However, the lifetime of T910 is still much higher than that of Kraft paper, even under higher aging temperature, which illustrates a relatively better thermal capability.

Table 4. Life (in hours) of insulating paper at each aging temperature.

\begin{tabular}{cccc}
\hline Life of Kraft (h) & $\mathbf{1 6 0}{ }^{\circ} \mathbf{C}$ & $\mathbf{1 4 0}{ }^{\circ} \mathbf{C}$ & $\mathbf{1 2 5}{ }^{\circ} \mathbf{C}$ \\
\hline Outer Layer & 138 & 1734 & 4044 \\
Inner Layer & 38 & 804 & 2718 \\
\hline Life of T910 (h) & $\mathbf{1 8 0}{ }^{\circ} \mathbf{C}$ & $\mathbf{1 6 5}{ }^{\circ} \mathbf{C}$ & $\mathbf{1 5 0}{ }^{\circ} \mathbf{C}$ \\
\hline Outer Layer & 576 & 2735 & 4878 \\
Inner Layer & 259 & 1583 & 3408 \\
\hline
\end{tabular}




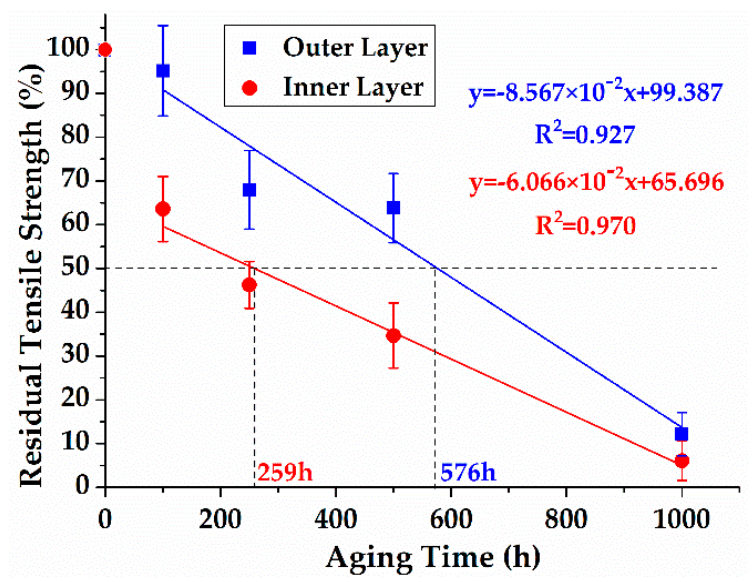

(a)

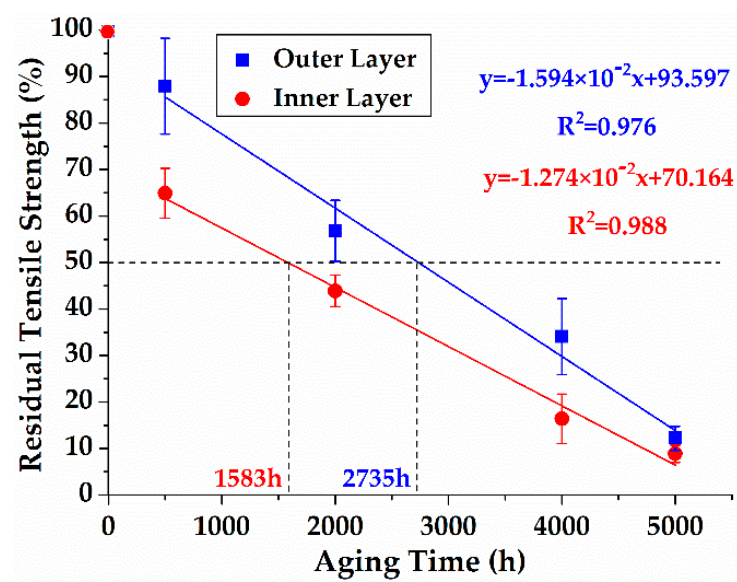

(b)

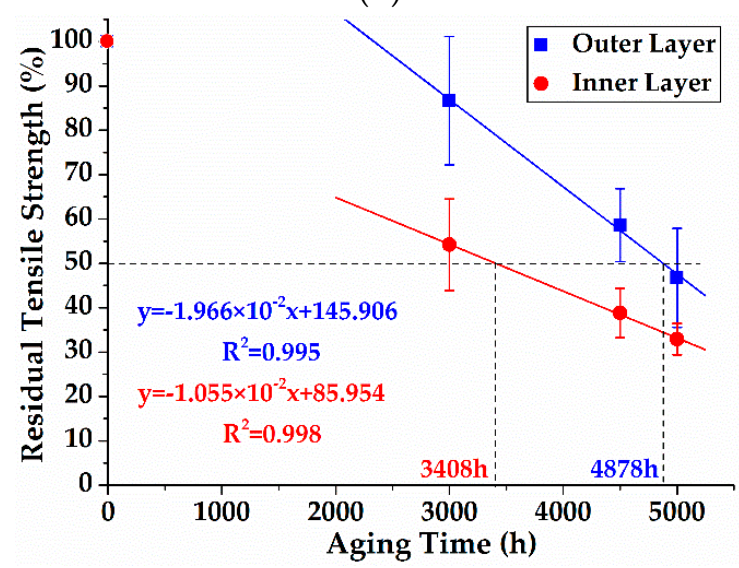

(c)

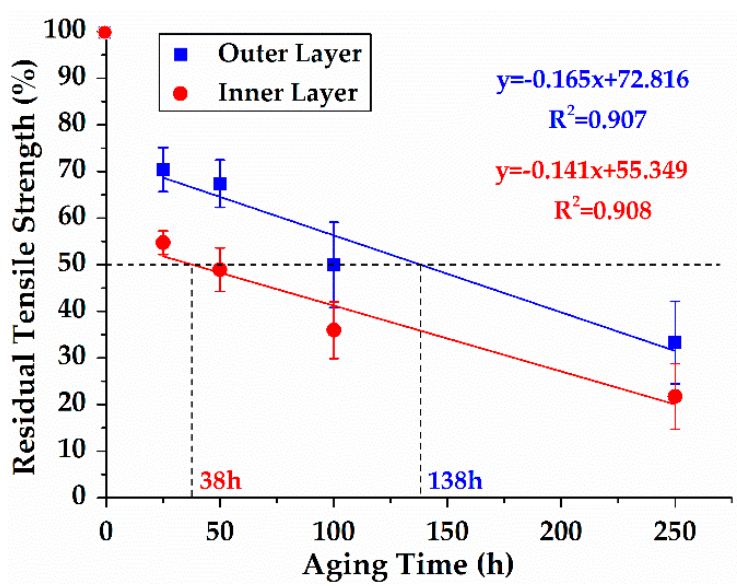

(d)

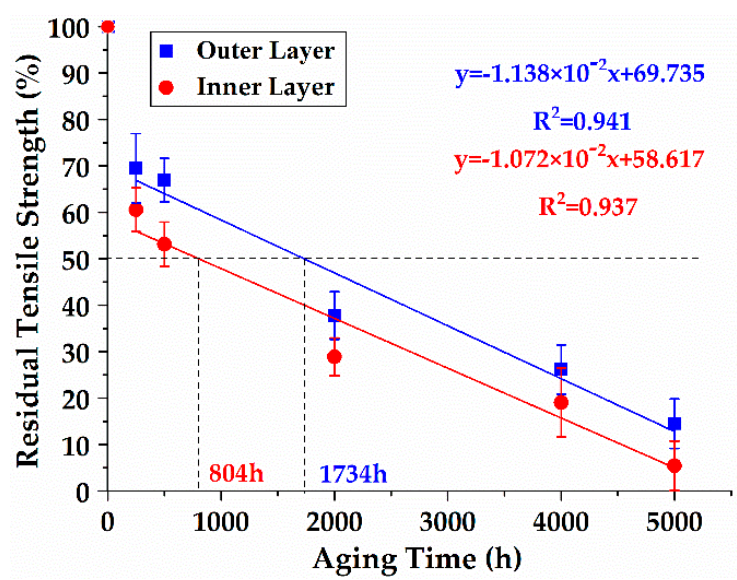

(e)

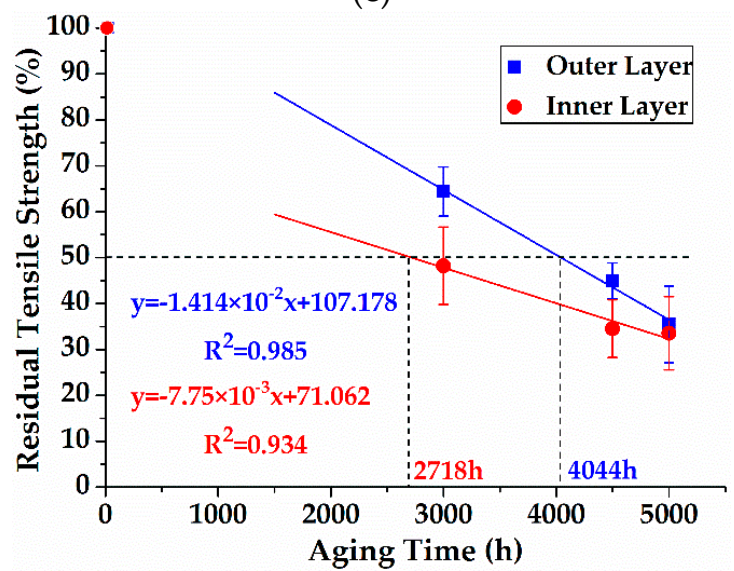

(f)

Figure 7. Residual tensile strength of T910 in FR3 and Kraft in mineral oil at different temperatures: (a) T910 at $180{ }^{\circ} \mathrm{C}$; (b) T910 at $165^{\circ} \mathrm{C}$; (c) T910 at $150{ }^{\circ} \mathrm{C}$; (d) Kraft at $160{ }^{\circ} \mathrm{C}$; (e) Kraft at $140{ }^{\circ} \mathrm{C}$; (f) Kraft at $125^{\circ} \mathrm{C}$. 


\subsection{Thermal Index (TI) of Insulation Systems}

According to the Arrhenius equation, there is a relationship between the chemical reaction rate and thermodynamic temperature. Thus, the relationship between the thermal aging lifetime and aging temperature of an insulation system can be given as Equation (2):

$$
\log L=A+\frac{B}{T+273}
$$

where $L$ represents the lifetime of a certain insulation system in hours, $T$ represents temperature in ${ }^{\circ} \mathrm{C}$, and $A$ and $B$ are constants. According to Equation (2), the thermal aging life curves of two insulation systems are plotted in Figure 8.

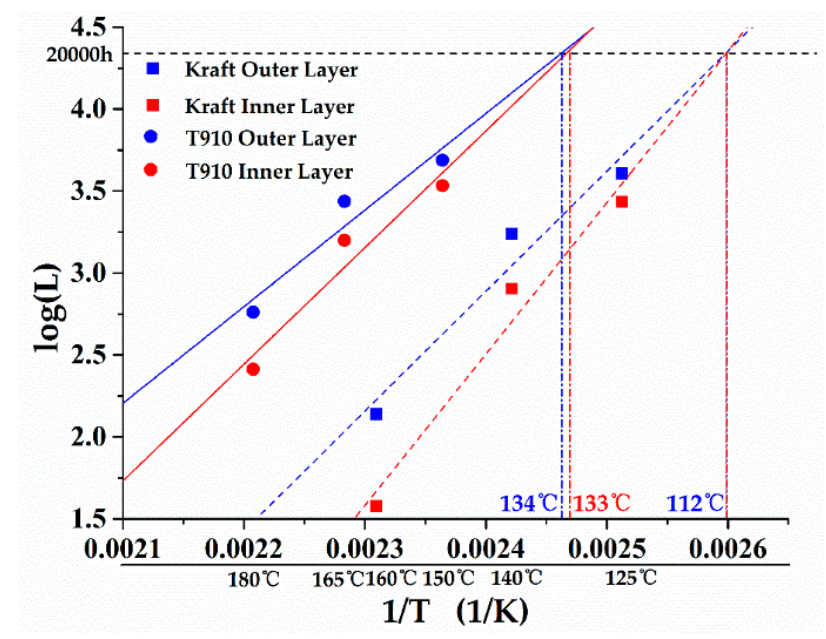

Figure 8. Thermal aging life curves of insulation systems.

Comparing the two different positions, the heat dissipation condition of the outer layer paper is better than that of the inner layer paper, which leads to the lifespan of the outer layer paper being relatively higher under the same temperature. However, the gap of thermal aging life curves between inner and outer layer samples was reduced under low thermal aging temperatures. Normally, the intermediate oil temperature is controlled at $115^{\circ} \mathrm{C}$, which is lower than the aging temperature of paper. Once the thermal aging temperature of insulating paper is low, the temperature difference between insulating paper and oil decreases. Furthermore, the thermal environment of the insulation system inside and outside tends to be consistent. The slope of the life curve of the outer layer paper is less than the life curve of the inner layer paper, and finally, intersects along with the decrease of thermal aging temperature.

TI refers to the value of Celsius temperature when the lifetime curve is 20,000 $\mathrm{h}$. The TI of inner layer T910 impregnated with FR3 is $133^{\circ} \mathrm{C}$, lower than that of the outer layer at $134{ }^{\circ} \mathrm{C}$. In the MO impregnated Kraft insulation system, the TI of the inner and outer layer paper is approximately $112{ }^{\circ} \mathrm{C}$. The heat resistance of the FR3 impregnated T910 insulation system is much higher than that of the MO impregnated Kraft insulation system.

\subsection{Dielectric Strength of Insulating Paper}

Dielectric strength is also one of the important properties of insulation paper, which directly provides insulation protection for winding. The breakdown voltages of insulating paper under different temperatures in different aging cycles were measured and plotted, as shown in Figure 9. Since the insulation paper was wrapped on a copper conductor, creases are unavoidable on its surface. In order to reduce the influence of creases on the breakdown voltage of insulation paper, the VDE electrode was adopted for step-up voltage tests with $50 \mathrm{~Hz}$ power supply frequency and $0.5 \mathrm{kV} / \mathrm{s}$ 
step-up speed. In these tests, T910 was placed in preconditioned FR3, and Kraft was placed in preconditioned mineral oil. The breakdown voltage of each sample was measured 20 times. All results were plotted by Weibull distribution, and the value with $63.2 \%$ breakdown probability was considered as the final result. Considering that the thickness of both candidate insulating papers are the same, their breakdown voltages can be directly compared.

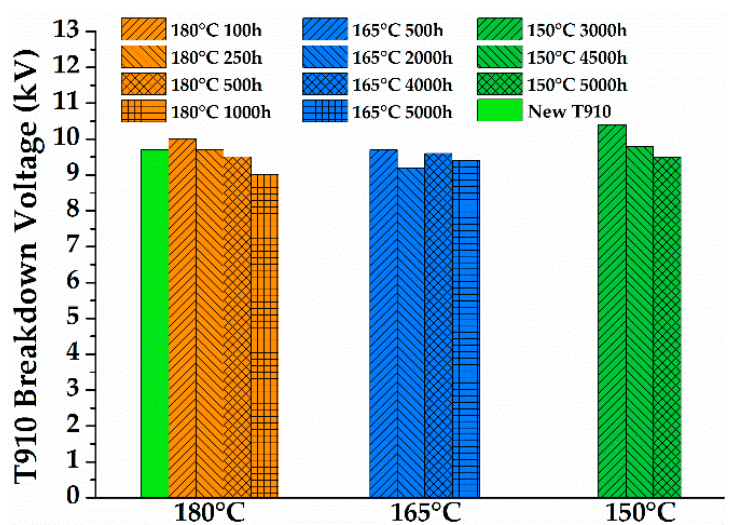

(a)

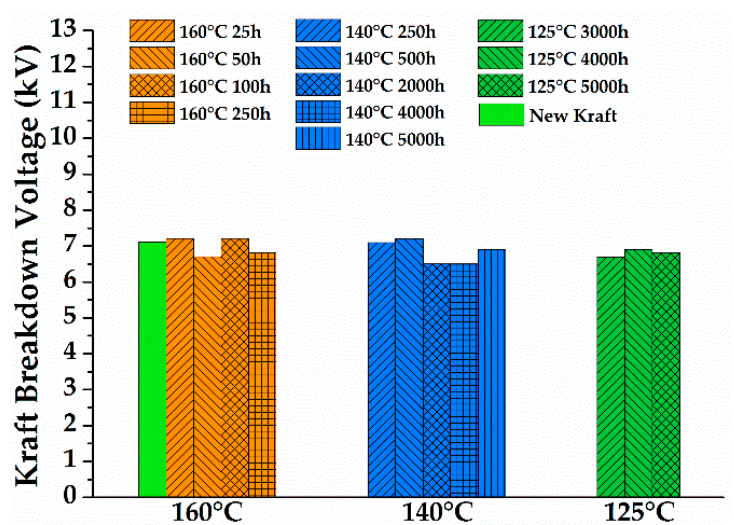

(b)

Figure 9. Breakdown voltage of aged insulating paper: (a) aged T910; (b) aged Kraft paper.

For the initial value of new insulating paper, T910 has better dielectric property breakdown voltage (T910: $9.7 \mathrm{kV}$; Kraft paper: $7.1 \mathrm{kV}$ ). Compared with the new paper, the maximum voltage drops of T910 and Kraft paper after aging is $0.7 \mathrm{kV}$ and $0.6 \mathrm{kV}$ respectively, which is not significant for either. Different from tensile strength, breakdown voltage is stable throughout the aging process. Reference [19] also reported that even if the mechanical strength of insulating paper drops to $30 \%$ of its initial value, dielectric strength can still maintain a relatively high level.

\section{Aging Test Results of Insulating Oils}

\subsection{Water Content}

Water content is one of the most important factors in the dielectrical performance of insulating oil [20], while water modules will accelerate the aging process for oil-paper. Coulometric Karl Fisher titration methodology was adopted in this study by Metrohm 831 KF coulometer and 860 KF Thermoprep. Considering similar trends under different temperatures, a typical thermal aging temperature was chosen to be measured for each insulation system, as shown in Figure 10 (aged oil under temperatures of $165^{\circ} \mathrm{C}$ and $140{ }^{\circ} \mathrm{C}$ for T910 and Kraft, respectively).

For mineral oil, the water content increased continuously throughout the aging process. The initial water content of FR3 was higher than that of mineral oil. However, the water content of FR3 showed different trends, increasing to the peak during the beginning of the aging process but dropping later. The water content in FR3 at the end of the aging test was even lower than at the start, which means that the water was consumed during the process. Similar changing of water content is shown in $[21,22]$, which suggests an accelerated aging rate in mineral oil compared to FR3, because hydrolysis, for which water is the reactant, is the main cause cellulose degradation of both Kraft and T910 [23]. Aramid has excellent chemical stability and is resistant to hydrolysis and oxidation, whose by-products, gas and water, are lower than the cellulose [24]. Paper [25] has illustrated that even under $240{ }^{\circ} \mathrm{C}$, aramid paper still retained $77 \%$ tensile strength in mineral oil after $5000 \mathrm{~h}$ thermal aging test. In addition, the maximum aging temperature within the tests is $180^{\circ} \mathrm{C}$, which is lower than pyrolysis temperature of aramid. As Figure 2 shows, cellulose fiber has been surrounded by aramid fiber to enhance the thermal resistance performance. 


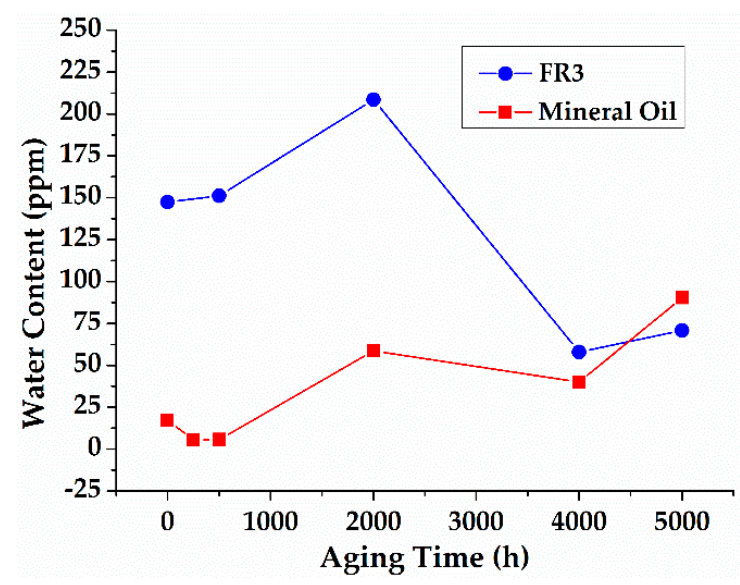

Figure 10. Water content of insulating oil under medium aging temperature $\left(165^{\circ} \mathrm{C}\right.$ for $\mathrm{T} 910$ aged in FR3 and $140{ }^{\circ} \mathrm{C}$ for Kraft aged in mineral oil).

Moreover, compared with mineral oil, FR3 has a higher saturated water content, which means that FR3 can absorb more water and decrease the water content of insulating paper.

\subsection{Dynamic Viscosity}

Insulating oil must be mobile to transfer the heat in a better manner from the core to the transformer radiators, where heat is dissipated. The dynamic viscosity of insulating oil is determined by relative molecular weight, in a relation shown by Mark-Houwink in the equation:

$$
\eta=K M^{a}
$$

where $\eta$ is dynamic viscosity, $a$ and $K$ are constants depending on the particular polymer-solvent system, and $M$ is the average molecular weight. In this paper, the dynamic viscosity of insulating oil was measured by a Brookfield LV-II pro viscometer fitted with a small sample adapter under $40^{\circ} \mathrm{C}$ and $90{ }^{\circ} \mathrm{C}$. Figure 11 shows the viscosity of oil under different thermal aging conditions: $165^{\circ} \mathrm{C}$ for $\mathrm{T} 910$ and $140{ }^{\circ} \mathrm{C}$ for Kraft. The dynamic viscosity of FR3 is significantly higher than that of mineral oil at the two temperatures, based on the relative molecular weight of triglyceride, which is a potential bottleneck for natural ester to be adopted in a liquid-immersed transformer. In this paper, the nitrogen protection of aging cells narrowed the variance of viscosity due to the limited oxygen reaction.

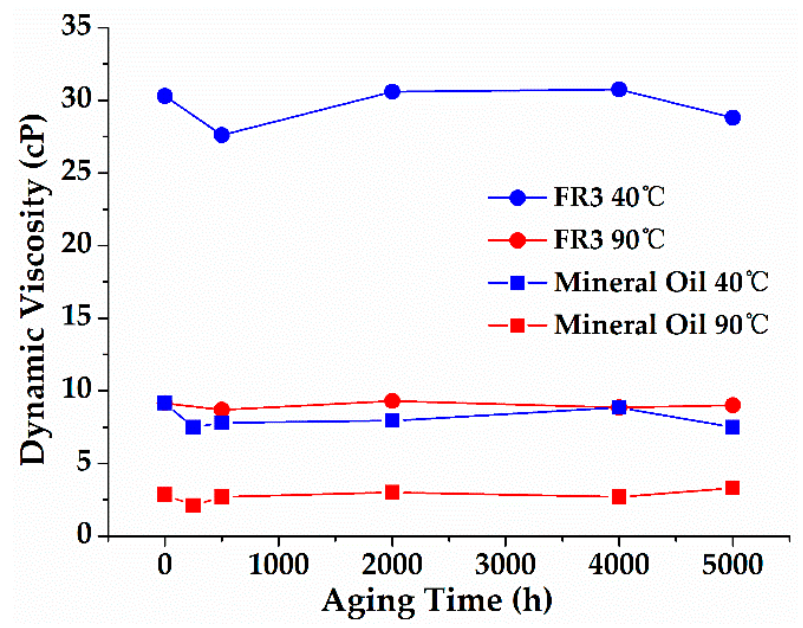

Figure 11. Dynamic viscosity of insulating oil under medium thermal aging temperature $\left(165^{\circ} \mathrm{C}\right.$ for T910 and $140{ }^{\circ} \mathrm{C}$ for Kraft). 


\subsection{Total Acidity}

The acidity of insulating oil speeds up the aging process of insulating paper, because hydrolysis of cellulose is catalyzed by $\mathrm{H}^{+}$[26]. In this paper, the acidity of insulating oil was measured by potentiometric titration with $\mathrm{KOH}$ isopropanol solution by Metrohm 848 Titrino plus equipment (Metrohm, Herisau, Switzerland). Considering the same pattern will be followed for acidity under different thermal aging temperatures, Figure 12 shows the total acidity of insulating oil under a typical aging temperature as an example.

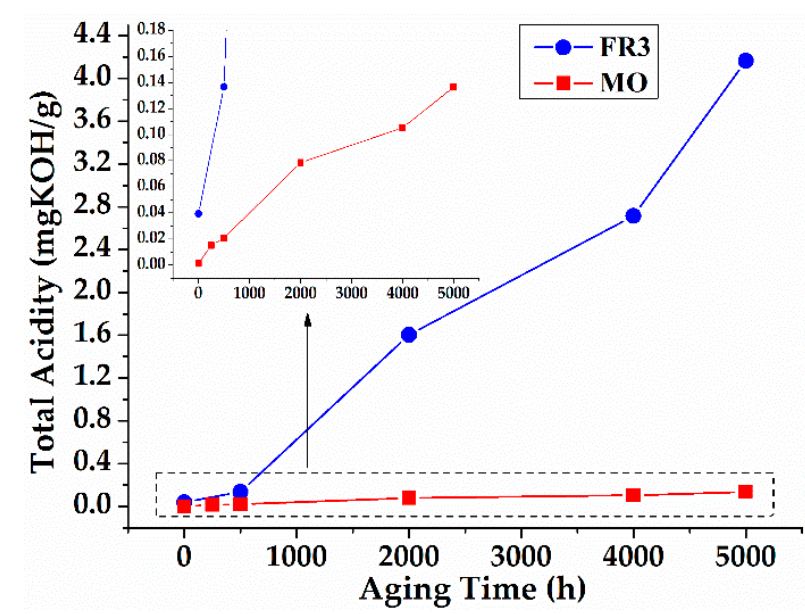

Figure 12. Total acidity of insulating oil under medium thermal aging temperature $\left(165^{\circ} \mathrm{C}\right.$ for $\mathrm{T} 910$ and $140{ }^{\circ} \mathrm{C}$ for $\mathrm{Kraft}$ ).

All thermal aging tests were conducted under nitrogen protection, with the acidity of insulating oil affected by $\mathrm{H}^{+}$generated from the hydrolysis of Kraft paper. Figure 12 shows the increasing acidity of mineral oil throughout the aging process. Compared with mineral oil, both initial value and speed of increase of the acidity of FR3 are higher due to the generation of fatty acid from the hydrolysis of glycerol fatty acid ester, which is the main component of natural ester. Different from carboxylic acid, fatty acid is a high-molecular acid that will not catalyze the hydrolysis of insulating paper [27]. In addition, a transesterification reaction between fatty acid and cellulose in T910 can form a barrier to water ingress and postpone the degradation of solid insulation [21,22]. In summary, a higher total acidity of FR3 cannot directly reflect the thermal aging status compared with mineral oil.

\subsection{Breakdown Voltage}

Breakdown voltage tests were conducted with a BAUR DTA 100C breakdown voltage machine (BAUR GmbH, Sulz, Austria), with reference to ASTM D1816 [28]. Step-up voltage tests were conducted with a $50 \mathrm{~Hz}$ power supply frequency and $0.5 \mathrm{kV} / \mathrm{s}$ step-up speed; the distance between electrodes was $1 \mathrm{~mm}$. For each insulating oil sample, the breakdown voltage tests were conducted 50 times at room temperature after each thermal aging cycle. All results were plotted by Weibull distribution, and breakdown voltage under probability equal to $63.2 \%$ was set as a benchmark, as shown in Figure 13.

As Figure 13a shows, the breakdown voltages of insulating oil have dispersion in a range. Based on statistical analysis principles, the value of breakdown voltage is adopted once the probability is $63.2 \%$. As Figure $13 b$,c shows, the initial breakdown voltage of FR3 is $41.1 \mathrm{kV}$, and that of mineral oil is $39.4 \mathrm{kV}$. For FR3, the difference of temperature and aging time has a limited impact except on the breakdown voltage under $180^{\circ} \mathrm{C}$ for $1000 \mathrm{~h}$, which is $31.2 \mathrm{kV}$. However, the lowest value of breakdown voltage is still higher than the controlling value of the related standard. In contrast, for mineral oil, the variance of breakdown voltage under different aging conditions is significant. 


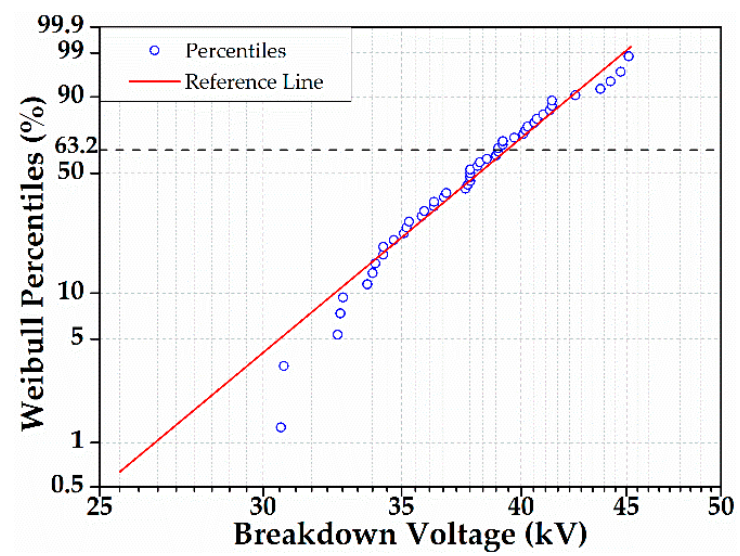

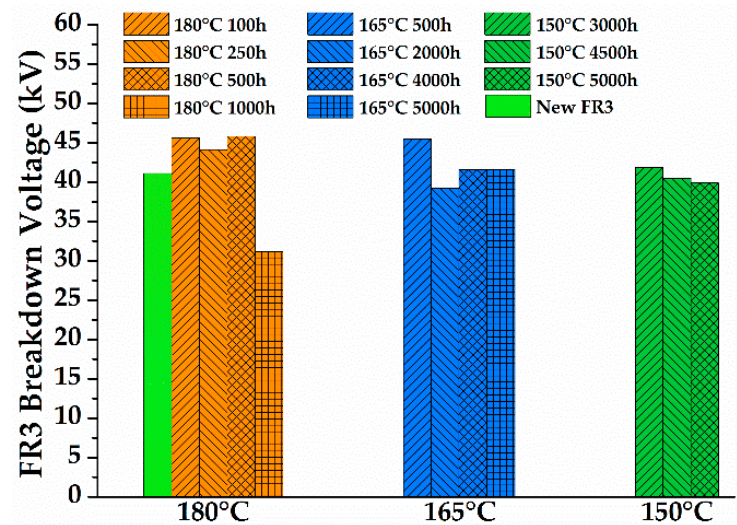

(b) (a)

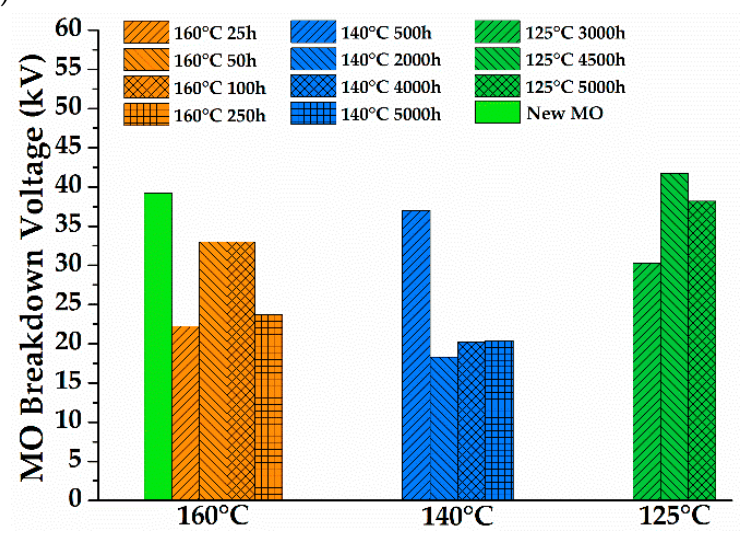

(c)

Figure 13. Breakdown voltage of insulating oil under different thermal aging conditions: (a) Weibull percentiles of new MO; (b) aged FR3; (c) aged MO.

According to a related study, the breakdown voltage of mineral oil is more sensitive to water content compared with natural ester [24]. For example, the saturated water content of mineral oil is about $68 \mathrm{ppm}$, and that of FR3 is about $1100 \mathrm{ppm}$ at $25^{\circ} \mathrm{C}$ [29]. The water molecule within the mineral oil will be released once the water content increases to the limit, which brings the potential risk of breakdown. Compared with absolute water content, relative water content is meaningful as a reference that can be calculated by the ratio of water content to saturated water content. With the increase of water content, breakdown voltage dropped significantly for both FR3 and mineral oil [24,30]. From Figure 10, after aging at $165^{\circ} \mathrm{C}$, it was observed that the water content of FR3 increased from $151.2 \mathrm{ppm}$ after $200 \mathrm{~h}$ to $208.6 \mathrm{ppm}$ after $2000 \mathrm{~h}$, then decreased to $57.9 \mathrm{ppm}$ after $4000 \mathrm{~h}$. At the same time, the breakdown voltage of FR3 first decreased from $45.5 \mathrm{kV}$ to $39.2 \mathrm{kV}$ and then increased to $41.6 \mathrm{kV}$.

\section{Conclusions}

In this paper, a dual-temperature thermal aging platform was established to explore a high-temperature insulation system, Nomex T910 immersed by FR3, as long as the conventional insulation system is identified as the benchmark.

For solid insulation materials, even under higher thermal aging temperatures, the tensile strength of T910 dropped more slowly compared with Kraft paper; that means the thermal index of T910 is higher than that of Kraft paper. In addition, the variance of dielectric strength for solid insulation is smaller, and in particular, T910 showed better performance during the whole thermal aging process.

For fluids, the viscosity of both mineral oil and FR3 maintains a relatively similar level, which shows that the oxygen reaction between solid insulation and fluids is not evident under nitrogen 
protection. The acidity of FR3 is higher compared with mineral oil based on chemical composition. Fatty acid was generated by glycerol fatty acid ester after hydrolysis during the thermal aging process. However, esterification between fatty acid and cellulose will postpone the degradation of cellulose opposite to other acids. After thermal aging, the breakdown voltage of FR3 maintained a high level, except after $1000 \mathrm{~h}$ at $180^{\circ} \mathrm{C}$, but was still higher than the threshold of a related standard request.

In summary, compared with a conventional insulation system consisting of mineral oil and Kraft paper, the FR3 impregnated T910 insulation system meets overloading transformer needs, which will improve the reliability of distribution transformers.

Author Contributions: Conceptualization, Y.X.; data curation, L.R.; funding acquisition, X.L.; investigation, X.Z., L.R., and H.Y.; methodology, X.Z., L.R., Y.X., and B.H.; project administration, Y.X. and X.L.; supervision, Y.X. and Q.L.; validation, B.H.; visualization, H.Y.; writing—original draft, X.Z., L.R., and H.Y.; writing一review and editing, X.Z., L.R., H.Y., and Y.X.

Funding: This paper is funded by China Southern Power Grid with the project No. GDKJQQ20152010.

Acknowledgments: The authors particularly wish to thank Xiaogang Xu for his support on the operation status of the distribution transformers and Sheng Liang for support on the thermal calculation of distribution transformers.

Conflicts of Interest: The authors declare no conflict of interest.

\section{References}

1. State Grid Corporation of China. Technical Guide for High Overload Capacity Distribution Transformer of Rural Power Network; Q/GDW 11190:2014; China Electric Power Press: Beijing, China, 2015.

2. China Southern Power Grid. Technical Guidance of $10 \mathrm{kV}$ Over-Loading Fluid Filled Transformer; China Southern Power Grid: Guangzhou, China, 2015.

3. Cigre Working Group TF D1.01.10. Aging of Cellulose in Mineral-Oil Insulated Transformers; International Council on Large Electric Systems: Paris, France, 2007.

4. Frimpong, G.K.; Oommen, T.V. A survey of aging characteristics of cellulose insulation in natural ester and mineral oil. IEEE Electr. Insul. Mag. 2011, 27, 36-48. [CrossRef]

5. Yang, L.; Liao, R.; Sun, C. Influence of vegetable oil on the thermal aging rate of Kraft paper and its mechanism. In Proceedings of the 2010 International Conference on High Voltage Engineering and Application (ICHVE), New Orleans, LA, USA, 11-14 October 2010.

6. McShane, C.P.; Rapp, K.J.; Corkran, J.L. Aging of paper insulation in natural ester dielectric fluid. In Proceedings of the 2001 IEEE/PES Transmission and Distribution Conference and Exposition, Atlanta, GA, USA, 2 November 2001.

7. Lee, K.; Szewczyk, R.; Zhou, Y. A new insulation system for liquid-immersed distribution transformers. In Proceedings of the 5th European Conference on HV \& MV Substation Equipments Power Utilities (MATPOST 2015), Lyon, France, 24-25 November 2015.

8. Zhang, X.; Shen, S.; Xu, Y. Thermal Evaluation of High-Temperature Insulation System for liquid-immersed transformer. In Proceedings of the IEEE Electrical Insulation Conference (EIC 2016), Montreal, QC, Canada, 19-22 June 2016.

9. IEEE C57.100 Working Group. IEEE Standard Test Procedure for Thermal Evaluation of Insulation Systems for Liquid-Immersed Distribution and Power Transformers; IEEE Std C57.100 ${ }^{\mathrm{TM}}-2011$ (Revision of IEEE Std C57.100-1999); IEEE: New York, NY, USA, 2011.

10. International Electrotechnical Commission (IEC). Electrical Insulation Systems (EIS)—Thermal Evaluation of Combined Liquid and Solid Components_Part 2: Simplified Test; IEC TS 62332-2:2014; IEC: Geneva, Switzerland, 2014.

11. International Electrotechnical Commission (IEC). Electrical Insulation Systems (EIS)—Thermal Evaluation of Combined Liquid and Solid Components_Part 1: General Requirements; IEC TS 62332-1:2011; IEC: Geneva, Switzerland, 2011.

12. Wicks, R.C. Insulation system for liquid-immersed transformers-New materials require new methods for evaluation. In Proceedings of the IEEE Electrical Insulation Conference (EIC 2009), Montreal, QC, Canada, 31 May-3 June 2009. 
13. Xu, Y.; Qian, S. Oxidation Stability Assessment of a Vegetable Transformer Oil under Thermal Aging. IEEE Trans. Dielectr. Electr. Insul. 2014, 21, 683-692. [CrossRef]

14. Lawson, W.G.; Simmons, M.A. Thermal Aging of Cellulose Paper Insulation. IEEE Trans. Dielectr. Electr. Insul. 1977, EI-12, 61-66. [CrossRef]

15. Montsinger, V.M. Loading Transformers by Temperature. Trans. Am. Inst. Electr. Eng. 1930, 49, 776-790. [CrossRef]

16. American Society for Testing and Materials International (ASTM International). Standard Test Method for Tensile Properties of Paper and Paperboard Using Constant-Rate-of-Elongation Apparatus; ASTM D828-16; ASTM International: West Conshohocken, PA, USA, 2016.

17. International Electrotechnical Commission (IEC). Electrical Insulation Materials-Thermal Endurance Properties_Part 3: Instructions for Calculating Thermal Endurance Characteristics; IEC TS 60216-3:2009; IEC: Geneva, Switzerland, 2009.

18. International Electrotechnical Commission (IEC). Electrical Insulation Materials-Thermal Endurance Properties-Part 2: Determination of Thermal Endurance Properties of Electrical Insulating Materials-Choice of Test Criteria; IEC TS 60216-2:2005; IEC: Geneva, Switzerland, 2005.

19. Shroff, D.H.; Stannett, A.W. A Review of Paper Aging in Power Transformers. In IEE Proceedings C-Generation, Transmission and Distribution; IET: Washington, DC, USA, 1985; Volume 132, pp. 312-319.

20. Sierota, A.; Rungis, J. Electrical Insulating Oils Part I: Characterization and Pre-treatment of New Transformer Oils. IEEE Electr. Insul. Mag. 1995, 11, 8-20. [CrossRef]

21. Liao, R.; Liang, S.; Yang, L. The Improvement of Resisting Thermal Aging Performance for Ester-immersed Paper Insulation and Study on Its Reason. In Proceedings of the 2008 Annual Report Conference on Electrical Insulation Dielectric Phenomena, Quebec, QC, Canada, 26-29 October 2008.

22. Rapp, K.J.; McShane, C.P.; Luksich, J. Interaction Mechanisms of Natural Ester Dielectric Fluid and Kraft Paper. In Proceedings of the IEEE 15th International Conference on Dielectric Liquids (ICDL), Coimbra, Portugal, 26 June-1 July 2005.

23. Arroyo, O.H.; Jalbert, J. Temperature dependence of methanol and the tensile strength of insulation paper: Kinetics of the changes of mechanical properties during ageing. Cellulose 2017, 24, 1031-1039. [CrossRef]

24. Cigre Working Group WG A2.35. Experience in Service with New Insulating Liquids; International Council on Large Electric Systems: Paris, France, 2010.

25. McNutt, W.J.; Provost, R.L. Thermal life evaluation of high temperature insulation systems and hybrid insulation systems in mineral oil. IEEE Trans. Power Deliv. 1996, 11, 1391-1399. [CrossRef]

26. Lundgaard, L.E.; Hansen, W. Ageing of oil-impregnated paper in power transformers. IEEE Trans. Power Deliv. 2004, 19, 230-239. [CrossRef]

27. Lundgaard, L.E.; Hansen, W. Aging of Mineral Oil Impregnated Cellulose by Acid Catalysis. IEEE Trans. Dielectr. Electr. Insul. 2008, 15, 540-546. [CrossRef]

28. American Society for Testing and Materials International (ASTM International). Standard Test Method for Dielectric Breakdown Voltage of Insulating Liquid Using VDE Electrodes; ASTM D1816-12; ASTM International: West Conshohocken, PA, USA, 2012.

29. Tenbohlen, S.; Jovalekic, M.; Bates, L. Water Saturation Limits and Moisture Equilibrium Curves of Alternative Insulation Systems. In Proceedings of the CIGRE SC A2 \& D1 Joint Colloquium 2011, Kyoto, Japan, 11-16 September 2011.

30. Wang, X.; Wang, Z.D. Particle Effect on Breakdown Voltage of Mineral and Ester Based Transformer Oils. In Proceedings of the Annual Report Conference on Electrical Insulation and Dielectric Phenomena (CEIDP 2008), Quebec, QC, Canada, 26-29 October 2008.

(C) 2018 by the authors. Licensee MDPI, Basel, Switzerland. This article is an open access article distributed under the terms and conditions of the Creative Commons Attribution (CC BY) license (http://creativecommons.org/licenses/by/4.0/). 